\title{
Die verband tussen gemeentebouprosesse en missionale gemeente-ontwikkeling
}

\begin{abstract}
Authors:
André G. Ungerer ${ }^{1}$

Malan $\mathrm{Nel}^{2}$

Affiliations:

${ }^{1}$ Reformed Theological

College, University of

Pretoria, South Africa

${ }^{2}$ Department of Practical Theology, University of Pretoria, South Africa

Note:

This article is based upon a PhD-thesis conducted at the University of

Pretoria, with the title

'Die verband tussen gemeentebouprosesse

en missionale gemeenteontwikkeling: 'n Prakties

Teologiese studie'. Prof. Dr

Malan Nel was the study

leader. Acknowledgement

and thanks is also given

to Judy Coetsee and

Joyce Jordaan from the

Department of Statistics

for their help and guidance.

This article is published

in the Section Practical

Theology of the Society for

Practical Theology in South

Africa.
\end{abstract}

Correspondence to:

André Ungerer

email:

andreung@telkomsa.net

Postal address:

Posbus 6233, Flamwood

2572, South Africa

Dates:

Received: 02 Aug. 2010

Accepted: 17 Feb. 2011

Published: 19 May 2011

How to cite this article: Ungerer, A.G. \& Nel, M 2011, 'Die verband tussen gemeentebouprosesse en missionale gemeenteontwikkeling', HTS Teologiese Studies/ Theological Studies 67(2), Art. \#931, 11 pages. DOI: $10.4102 /$ hts.v67i2.931

C 2011. The Authors Licensee: OpenJournals Publishing. This work is licensed under the Creative Commons Attribution License.
This article dealt with the process of building up the local congregation and the manner in which missional objectives are achieved. The article was undertaken against the background of the disturbing decline in membership numbers, particularly in the two traditional Reformational churches in South Africa, namely the Dutch Reformed Church (DRC) and the Netherdutch Reformed Church of Africa. This decline is in line with similar tendencies in mainstream churches the world over. The key aspects of the theory of building up the local church was discussed and mission in the current South African context dealt with, particularly in view of the fact that an entirely new mission field has opened itself up with the influx into the country of so many people from neighbouring countries who have come to live in our midst. Missional objectives for the local church, as well as aspects that can be subjected to empirical testing are determined all along. The hypothesis wanted to verify whether local churches that have undergone a structured process of building up the local church are more successful missionally than those that have not undergone a structured process.

\section{Inleiding}

In Suid-Afrika strek die eerste spore van die vak Gemeentebou so ver terug as 1986, toe Malan Nel 'n eerste publikasie die lig laat sien het met die titel Teologiese Perspektiewe op Gemeentebou. Sedertdien het verskeie publikasies en artikels onder hierdie vakgebied verskyn (o.a. Nel 1986, 1988, 1994, 1995, 1998, 2002; Bischoff 1991, 1998; Hendriks 1992, 2004). Predikante het in wisselende grade van die vak kennis geneem, hetsy in die vorm van voortgesette opleiding of bekendstellingsgeleenthede wat bygewoon is. Dit wil tog blyk of daar gemeentes was wat ander gemeentes in hulle onmiddellike omgewing aangemoedig het om by die saak van gemeentebou betrokke te raak en dat daar 'n suurdeeg-effek aan die werk was. Dit is bykans onmoontlik om die eksponensiële invloedswaarde daarvan soos wat dit oor die land heen gespoel het, te verreken. Die indruk word verkry dat baie gemeentes wat nie 'n gestruktureerde gemeentebouproses deurloop het nie, tog sekere beginsels van gemeentebou geïmplementeer het vanweë hierdie soort beïnvloeding. Die toepassing van gemeenteboubeginsels, soos byvoorbeeld die kweek van die regte identiteitsbewussyn, het meegewerk om 'n goeie klimaat vir missionale bewussyn in gemeentes te skep.

In dieselfde tyd wat die vak Gemeentebou in Suid-Afrika die lig gesien het, het 'n ontstellende tendens te voorskyn getree, naamlik die afname van die tradisionele Reformatoriese kerke se lidmaatgetalle. Die vraag kan tereg gevra word of gemeentebouprosesse in talle gemeentes enigsins daarin kon slaag om die afname in lidmaatgetalle te stuit of selfs om dit effektief te keer. Vir eers word daar ondersoek ingestel na die afname in lidmaatgetalle.

\section{Die verlies aan lidmaatgetalle}

Dit is nie net in Suid-Afrika waar gevestigde hoofstroomkerke lidmate verloor nie, maar ook in Europa en die VSA (vgl. Hoek 1999; Mann 1999:ix; Gibbs 2000:10; Driscoll 2006; Barna 2005; Niemand 2007). Hirsch (2006:36) oordeel dat nóg die tradisionele hoofstroomkerke, nóg die onafhanklike megakerke die styging in ongeloof en buitekerklikheid kon stuit. Dreyer (2003:1051-52) noem dat waar die draaipunt in die VSA in 1965 was, dit in Suid-Afrika in 1985 begin het. Die Reformatoriese kerke se markaandeel was 33\% in 1911 en het sedertdien tot 16\% in 1991 gedaal. Volgens Oliver (2006:126), het die Nederduitse Gereformeerde Kerk (NGK), wat die grootste Afrikaanssprekende kerk is, meer as 270000 lidmate die afgelope 20 verloor. Die tradisionele Afrikaanse kerke, die Nederduitsch Hervormde Kerk (NHKA), die NGK en die Gereformeerde Kerke, het saam 375163 lidmate gedurende die afgelope 21 jaar verloor, waarvan die dooplidmate gedurende hierdie periode die grootste verlies verteenwoordig het, naamlik 65\% óf 243646 (Dreyer 2009:6).

As die statistieke van die NHKA verder ontleed word, is daar sedert 1992 'n konstante afname in lidmaatgetalle. Vanaf 1971 was daar 'n konstante groei vanaf 109240 belydende lidmate tot 
'n hoogtepunt in 1992 met 134160 belydende lidmate. In die 16 jaar sedertdien, het die belydende lidmaattal tot 107202 afgeneem (Almanak 2009:167).

Wanneer daar rondgevra word oor redes waarom die kerk se getalle afneem, word baie antwoorde verkry. Kerke se studiestukke verdink sekularisasie, materialisme, fundamentalisme, liberalisme, formalisme, postmodernisme en nog ander '-ismes' as die oorsaak daarvan (Van Staden 2007:12). Hierby voeg Van Wyk (2007:10) nog kwessies soos internasionalisering of globalisering, asook die verandering van die vrou se rol in die ontwikkelde samelewing. George Barna (2005:118) wys dat navorsing in Amerika daarop dui dat die plaaslike kerk feitlik geen invloed op die Amerikaanse kultuur het nie. Die sewe dominante sfere van beïnvloeding in die samelewing is rolprente, musiek, televisie, boeke, die internet, die reg en die familie. Die tweede reeks entiteite wat die samelewing beïnvloed, bestaan uit eenhede soos skool, portuurgroep, nuusblaaie, die media en besigheid. Die plaaslike kerk is onder die entiteite wat min of geen invloed op die samelewing het nie. Volgens Niemandt (2007:13) is die invloed van die Christelike kerke in ontwikkelde lande op 'n laagtepunt, miskien die laagste in die geskiedenis.

\section{'n Hipotetiese vertrekpunt}

Daar is reeds verwys na die rol wat die vak gemeentebou sedert die middel 1980s in Suid-Afrika gespeel het. Daar is oor die kommerwekkende daling in lidmaatgetalle onder die tradisionele Reformatoriese kerke in Suid-Afrika gehandel. Die vraag onstaan of gemeentes uit die Reformatoriese tradisie met hulle missionale aktiwiteite daarin slaag om die kwynende lidmaatgetalle te stuit en of die vak Gemeentebou en die aanwending van gemeenteboubeginsels ' $n$ bepalende rol daarin vervul of nie. Die volgende word as hipotese gestel:

Gemeentes wat besig is met' $n$ gestruktureerde gemeentebouproses, is missionaal meer suksesvol as gemeentes wat geen gestruktureerde gemeentebouproses deurloop nie.

Die werkswyse om hierdie hipotesestelling te verifieer of verkeerd te bewys is soos volg:

- 'n Bondige omskrywing van 'n gestruktureerde gemeentebouproses.

- 'n Omskrywing van wat 'n missionale gemeente behoort te wees en die empiriese toetsing waaraan gemeentes onderwerp is.

- 'n Finale bevinding.

\section{Gemeentebou}

Die werksformule van Nel $(1994: 14,216)$ dien as definisie: gemeentebou is die bediening waarbinne die gemeente opgelei en begelei word om:

- haar eie wese en bestaansdoel te verstaan

- self, as gemotiveerde gemeente, haar eie funksionering te evalueer, doelwitte vir haar doelgerigte funksievervulling te formuleer en op beplande wyse te bereik

- self, soos nodig, op 'n voortgaande basis strukture, wat die heilshandelinge van die drie-enige God in kerk en wêreld dien, vir die gemeentelike funksionering te ontwikkel.

Gemeentebou is 'n omvangryke vakgebied en die volgende word as bondige uitgangspunte oor gemeentebou gestel.

\section{'n Proses van transformasie}

Baie gemeentes is vasgevang in wat Getz (1984:40) 'fixity' noem, die vashou aan ' $n$ bepaalde vorm of 'bunker mania' soos Sweet (1999:20) daarna verwys. Nel (1994:15) noem dat enige vorm van gemeenteverval fataal en niks anders as sonde is nie.

Die gemeente staan bekend as die gedefinieerde subjek (Nel 1994:12, 1995:860). As daar gepraat word van die gemeente as gedefinieerde subjek, is dit soos God bedoel het dat die gemeente moet wees. Die gemeente op aarde lyk egter dikwels anders en word die empiriese subjek genoem. Tussen die gedefinieerde subjek en die empiriese subjek kan daar op ' $n$ bepaalde tyd en plek 'n groot kloof wees. Vernuwing in gemeentebou gaan oor die vraag oor hoe die empiriese subjek nader kan kom aan (reformasie) en meer kan word van dit wat dit bedoel is om te wees, die gedefinieerde subjek.

\section{'n Proses van integrering en koördinering van bedieninge}

Nel (1994:10) wys ook op die gevaar daarin om alles wat die opbou van die gemeente dien, gemeentebou te noem. Hy (Nel 1994:10, 1998:30) beklemtoon dat aspekte soos prediking, erediens, pastorale sorg, getuienis na buite, kategese, jeugbediening, koinonia en dienslewering nie noodwendig gemeentebou is nie. Gemeentebou kan nie sonder een van hierdie bedieninge slaag nie, maar dit is tog meer as die somtotaal daarvan.

Die totale bediening is diensbaar aan die opbou van die gemeente, maar gemeentebou is nie maar net die somtotaal van alles wat in belang van die opbou van die gemeente gebeur nie. Die vraag kan tereg gevra word dat as gemeentebou net die somtotaal van bedieninge is, waarom daar dan nie meer opgeboude gemeentes is nie. Dit is egter net so misleidend om van gemeentebou ' $n$ aftreksom te maak. In hierdie geval word die minder wesenlike afgetrek en dit wat oorbly, word bymekaar gemaak om gemeentebou te verkry. Gemeentebou is ook nie 'n deelsom waar alles deur een bepaalde bediening, soos byvoorbeeld koinonia, gedeel kan word nie. Koinonia is dan die enigste bediening waaraan toegespitste aandag gegee word. Gemeentebou is eerder ' $n$ vermenigvuldigingskonsep, waarin integrering en koördinering in belang van die geheel plaasvind (Nel 1994:10). Binne hierdie gemeenskap wend gelowiges gesamentlik en afsonderlik hulle gawes tot nut en saligheid van mekaar aan (Kyk ook Hendriks 1990:130, 1992:69,86; Te Velde 1992:65-73; Hoek 1999:75; Van der Merwe \& Vos 2002:386; Schwarz 2005:108/109).

\section{Gemeentebou is ' $n$ langtermynbediening}

Gemeentebou is 'n prosesmatige bediening wat gerig is op 
die voortdurende vernuwing van die gemeente (Nel 1994:12). Uiteraard verloop hierdie proses oor ' $n$ lang termyn en is dit nie iets wat ooit afgehandel word nie. Dit onderstreep net weereens die belangrikheid van die lang verbintenis wat ' $n$ pastor met 'n gemeente behoort te hê (vgl. Gibbs 1993:146; Warren 1995:31 en Van der Merwe 2005:5). Volgens Stevens en Collins (1993:7) is nie net 'n lang verbintenis nodig nie, maar ook om deel van die gemeente te word. Hulle bepleit 'n sisteembenadering en nie net bloot 'n rolvervulling nie: 'It is not a question of roles; it's a matter of the heart'. 'n Pastor kan 'n gemeente net beïnvloed as hy of sy volledig deel raak daarvan. Die deel-raak-van 'n gemeente en die vernuwing wat daaruit kan voortspruit, is iets wat baie jare duur.

\section{Gemeentebou is afhanklikheid van God}

Wanneer met die gemeente van Jesus Christus besig is, kan mens nie anders as om te besef dat jy met God se gemeente besig is nie. Die Drie-enige God is soewerein en is deurgaans as Subjek aan die werk (vgl. Roberts 1963:24; Te Velde 1992:13; Hendriks 1992:40; Nel 1994:4,15; Beukes 1995:807; Heitink et al. 1998:13; Hoek 1999:14; Van der Merwe \& Vos 2002:371; Schwarz 2005:46-48; Heitink 2007:25-28). God is met sy gemeente besig en hy het sy gemeente liewer as wat ons dit ooit kan hê. Dit is daarom ondenkbaar dat 'n pastor en enige gemeenteboukommissie, gemeentebou in eie krag kan aanpak.

\section{'n Proses van identiteitsopleiding}

Motivering is ten diepste ' $n$ begeleiding tot ' $n$ identiteitsbewussyn (Nel 1994:127). Die gemeente moet toenemend gelei word om te verstaan wie hulle werklik in Christus is (Nel 1998:29). Dit gaan daaroor om 'n besielde gemeenskap van dissipels van Jesus Christus te vorm (Kyk ook Du Plessis 1962:79; Hendriks 1990:15; Te Velde 1992:56; Hoek 1999:17-18; Schwarz 2005:110). Daar moet by die gemeente 'n korporatiewe identiteitsbewussyn geskep word. Hierdie korporatiewe selfbeeld moet as teenvoeter vir 'n indiwiduele identiteitswaarde dien. By die gemeente wat besig is om haar identiteit te vind gaan dit baie keer soos die identiteitsoeke wat by adolessente aangetref word. Dit gaan oor vrae soos: Wie is ek? Wat glo ek? Wat is my verhouding tot ander? Dit is alles wesenlike identiteitsvrae. Nel (1998:29) noem dat hierdie geskenkte selfbeeld en status ontdek word om vanuit die gegewe 'status' te leef; dit is gemeente se identiteit wat in Christus te vind is. Die sola gratia en sola fide van die gemeente se bestaan moet ook ernstig geneem word.

\section{'n Gestruktureerde gemeentebouproses}

In die hipotesestelling word twee keer pertinent verwys na die gestruktureerde gemeentebouproses: gemeentes wat besig is met 'n gestruktureerde gemeentebouproses is missionaal meer suksesvol as gemeentes wat geen gestruktureerde gemeentebouproses deurloop nie. Dit is daarom belangrik om uit te mak wat die kriteria vir 'n gestruktureerde gemeentebouproses is.

\section{Gestruktureerd}

Odendal en Gouws (2000) dui aan dat die woord struktureer (gestruktureer) beteken om " $n$ struktuur aan te bring in; tot 'n saamgestelde, strukturele geheel te maak'. Die woord struktureer word as 'n werkwoord aangedui. Dit sou in gemeenteboutaal kon beteken dat struktuur aan die proses gegee moet word ten einde die proses as 'n saamgestelde, strukturele geheel te laat verloop.

\section{Gemeentebou}

Die definisie van gemeentebou is reeds behandel. Die vraag oor wanneer 'n gemeente met gemeentebou besig is, ontstaan onwillekeurig. Beteken dit byvoorbeeld dat daar 'n aanloop moet wees tot 'n analisenaweek, wat deur 'n konsultant aangebied word en die opstel van 'n visie en missiedoelstellings onder leiding van 'n konsultant wat dan ook die hele proses verder monitor? Dit sou sekerlik as 'n ideale scenario kon dien. Maar daar is ook ander voorbeelde van pastors met 'n sterk 'gemeenteboufilosofie', wat die proses in hulle eie gemeentes geïnisieer en laat verloop het.

\section{Proses}

' $n$ Proses is ' $n$ ontwikkelingsgang, byvoorbeeld ' $n$ chemiese proses, 'n proses van vervaardiging ensovoorts (Odendal \& Gouws 2000). 'n Proses kan eenvoudig opgesom word as 'n traps- of stapsgewyse, toenemende beweging en verloop om by 'n bepaalde doelwit uit te kom. Dit veronderstel 'n aanloop, 'n ontwikkelingsgang, metodes, voortdurende aksie, beweging, verandering, verloop, afloop en die nastrewing van die doelwit. Daarby kan aspekte soos tydskedules en evaluasie gevoeg word en wat in die empiriese studie verreken is.

\section{Deelnemende gemeentes in die empiriese studie}

By die aanlê van die toetsing, was die veronderstelling dat daar vanuit 'n redelike databasis van gemeentes wat 'n gestruktureerde gemeentebouproses deurloop het, gewerk word. Sodanige databasis is van Malan Nel, wat sedert 1988 as gemeenteboukonsultant by gemeentes betrokke is, verkry. Uit sy rekords van hierdie gemeentes kon met gemak 90 gemeentes geïdentifiseer word waar hy die Callahan-analise gedoen het en waar hy by die daarstelling van elke gemeenteboureëlingskomitee se eerste visie- en doelwitformulerings betrokke was.

Om 'n vergelykende databasis te kry waaraan die missionale sukses van gemeentes wat 'n gestruktureerde gemeentebouproses deurloop (hierna verwys as gemeentebougemeentes) gemeet kon word, is daar gesoek na gemeentes wat hulle in dieselfde geografiese en sosioekonomiese konteks bevind. Die mees voor die hand liggende werkswyse was om gemeentes te identifiseer wat nie 'n gestruktureerde gemeentebouproses deurloop nie (hierna verwys as nie-gemeentebougemeentes), wat in dieselfde 
ring geleë is as die gemeentebougemeentes. 'n Tabel is opgestel met al die gemeentebougemeentes in hulle bepaalde ringe met ' $n$ lys van al die ander gemeentes in dieselfde ring. Voorts is tussen die twee denominasies, die NHKA en die NGK onderskei. So is 'n Hervormde gemeentebougemeente byvoorbeeld aan 'n ander Hervormde gemeente in dieselfde ringgemeet. Die DepartementStatistiekvanUPhetvervolgens een vergelykende gemeente vir elke gemeentebougemeente in ' $n$ bepaalde ring aangewys. Uiteindelik is daar 180 vraelyste per gewone pos aan die gemeentebougemeentes en die geïdentifiseerde nie-gemeentebougemeentes versend. Van die NHKA het 12 gemeentes op die vraelyste reageer, terwyl 69 NGK gemeentes vraelyste teruggestuur het. 'n Totaal van 81 of $45 \%$ van die vraelyste is terugontvang. Hiervan het 36 gemeentes die Callahan-analise en Callahananalise-proses deurgeloop, terwyl vyf gemeentes ' $n$ ander gestruktureerde proses deurloop het. 'n Totaal van 40 gemeentes het geen gemeentebou of ander gestruktureerde proses deurloop nie. ' $n$ Totaal van 41 gemeentes sorteer dus onder die gemeentebougemeentes en 40 hoort onder die niegemeentebougemeentes tuis.

Daar moet vermeld word dat vyf van die gemeentebougemeentes ander gestruktureerde prosesse gevolg het. ' $n$ Gemeente in Pretoria is sedert 2008 by die Suid-Afrikaanse Vennootskap van Gestuurde Gemeentes (SAVGG) betrokke, terwyl 'n volgende Pretoriase gemeente 'n kombinasie van Christian Schwarz se Natural Church Development (NCD) en die Callahanbenadering gevolg het. Nog 'n plattelandse gemeente volg die NCD-model terwyl twee ander plattelandse gemeentes die model van die Kingfisher Mobiliseringsentrum volg en die model van die Duetgemeente in Potchefstroom.

Dit was opvallend dat net $53.9 \%$ van die gemeentebougemeentes steeds in ' $n$ bepaalde siklus is en $46.2 \%$ nie meer nie. Daar kan aanvaar word dat hierdie gemeentes wel nog stimulus uit die voorafgaande jare put en steeds 'n bepaalde gemeenteboufilosofie koester.

\section{Die missionale gemeente}

Die eerste sendingtaak van die kerk is nie om die wêreld te verander nie, maar om self te verander (Bosch 1979:246). Dit is ook wat Guder (2000) in sy boek, The Continuing Conversion of the Church, bedoel. Dit gaan oor' $n$ voortdurende herbesinning en terugkeer na die kernroeping van die kerk. Sending het sy oorsprong in die hart van God, die fontein van sendende liefde. "This is the deepest source of mission. It is impossible to penetrate deeper still; there is a mission because God loves people' (Bosch 1991:391-392). Soos Niemandt (2007:147-148) dit stel: 'Dit is nie 'n geval dat God sending doen nie - Hy is sending!' Verder ook:

Die kerk het nie sendingwerk nie, die kerk is God se sending aan die wêreld. Die kerk is gestuurde kerk. Ten diepste gaan dit nie oor die kerk nie, maar oor almal wat die Here deur die kerk wil seën. As die kerk hierdie insig verloor, verloor die kerk sy hart.

(Niemandt 2007:149)

Die vraag is hoeveel gemeentes insig het in bostaande waarhede? In hoe ' $n$ mate funksioneer die gemeente as missionale gemeente? Op watter wyse dra 'n gestruktureerde gemeentebouproses by tot die vergestalting van ' $n$ missionale gemeente?

\section{Die term 'missionaal'}

Die NHKA het tot op hede die term 'missionêr' gebruik. In 'n skrywe van die voorsitter van die komitee vir missionale gemeentes, Christo van der Merwe, gedateer 21 Julie 2008 aan die Kuratorium van die NHKA, word daar aangedui waarom die term 'missionaal' voortaan gebruik moet word, eerder as die term 'missionêr'. As vernaamste rede word aangevoer dat daar by sommige lidmate in die NHKA 'n negatiewe konnotasie aan die begrip missionêr geheg word. In die negatiefste sin beteken dit dat dit ' $n$ oorblyfsel is van Hervormers se onaangename ervaring van die sending- en politieke geskiedenis in Suid-Afrika. Minder negatief beskou, dui dit daarop dat die term 'missionêr' iets kommunikeer van 'wat ons bereid is om daar ver te doen met wat ons oor het'. Volgens die skrywe, beklemtoon die begrip missionaal 'n eie beslissing wat mense self in hulle hart maak, terwyl die begrip missionêr betrekking het op 'n aksie sonder dat die dader noodwendig sy of haar hart belê het in die saak wat deur die aksie geraak word. Met die term missionaal word gehoop dat daar iets van ' $n$ hartsverandering by lidmate sal plaasvind van 'hoe maak ons ' $n$ verskil met wat ons is waar ons is'.

\section{Apostolaat in die NHKA}

Daar is nog ' $n$ voorbeeld van nuwe denke in die NHKA wat betref die beleid van skeiding tussen evangelisasie en sending. Van der Merwe (Die Hervormer 2009:1) meen dat apostolaat voortaan holisties en geïntegreerd gedoen moet word. Die beleid van skeiding tussen evangelisasie en sending is nie meer van pas nie. Die Kerk het vir te lank die interafhanklikheid van verskillende bedienige misgekyk en alles in selfstandige entiteite en kompartemente opgebreek:

Elke gemeente, en die Kerk as geheel behoort ' $n$ holistiese en geïntegreerde benadering tot apostolaat te handhaaf. Die eredienste, diakonaat, pastoraat en gemeente-ontwikkeling het alles te doen met die apostolaat, en omgekeerd.

(Van der Merwe 2009:1)

\section{Missionale pouvere?}

Black en Gregersen (2008:87) praat van 'corporate peacock feathers' wanneer hulle verwys na die hele saak van 'n visie en missie wat by baie instellings ' $n$ modegier geword het. Die missionale gerigtheid in gemeentes word dikwels verwoord in visie- en missiestellings, wat binne in kerkgeboue pryk, terwyl daar dikwels nie veel daarvan realiseer in die alledaagse lewe van die gemeente en haar lidmate nie.

Sonder om enigsins afbreek te doen aan die verdienstelike poging om lewe te blaas in die NHKA se missionale funksionering en apostolaatsbeleid, wonder 'n mens of die nuwe taalgebruik nie iets van 'missionale pouvere' is waarvan die glans mettertyd sal verdof nie. Laat ons hoop en bid dat die teendeel eerder 'n werklikheid word, nie net vere 
nie, maar 'n pou wat trots die skoonheid vertoon en die wese vergestalt van wat dit bedoel is om te wees.

\section{Missionale karakter}

'n Missionale identiteit kan nie anders as om in 'n missionale karakter uit te mond nie. Callahan (1990 vgl. 2000) sê die volgende:

The church is called for the integrity of mission and not for the sake of church growth. We are called to share the Kingdom, not to grow churches. The fundamental category for this time is mission, not church. What we need is mission growth.

(Callahan 1990:19; vgl. 2000:59)

Gibbs (2000:42) waarsku soos volg: ‘We must always look beyond numbers. The issue is not who can attract the biggest crowd but who is making the biggest impact on society'. Ook McManus (2001:23; vgl. Van der Merwe 1997:717) meen dat die kerk haar weg verloor as oorlewing die hoofdoel geword het. Die doel van die kerk kan nie net wees om te oorleef nie, maar om uit te reik en te dien. Moffitt (2006) sê die volgende:

But the primary goal of the church should not be numerical growth! Sometimes, numerical growth comes at any cost, including softening the message to not offend or challenge the ungodly aspects of our cultures.

(Moffitt 2006:183)

Hoe moet daar dan oor getallegroei gedink word? Nel(1994:38, 237) noem tereg dat die gemeente ten diepste God se mense is wat hom in hierdie wêreld dien en verteenwoordig. Hy noem dat die kerklike samelewing deur 'n verbruikersmentaliteit aangetas is. Ons het dit almal onder lede, soos kinders wat aan 'n kindersiekte ly, selfs al is daar nog geen uitslag nie. Almal vra bewus en onbewus: Wat bied dit my? Wat kan ek daaruit kry? Hoe pas dit my? Hoe is die diens, goed of sleg? Ook Gibbs (2000:41-42) lewer insiggewende kritiek in die algemeen op wat hy 'The Marketing Mentality' noem. Kerke wat 'n verhoogde erediensbywoning beleef, behoort bedag te wees op wat Gibbs (2000:41), 'a premature sense of achievement' noem. Die vraag moet altyd gevra word waar die mense vandaan kom. Is 'n betrokke kerk besig om ten koste van ander gemeentes te groei? (Kyk ook Sider et al. 2002:67). Warren (2002:116) sien ook die potensiële gevaar en verwys na die kultuur van onafhanklike indiwidualisme: 'Skyngelowiges wat van die een kerk na die ander spring, sonder enige identiteit, toerekenbaarheid of toewyding'.

Die volgende kan as kriterium gestel word vir die gemeente se nadenke oor getallegroei:

- Dit moenie die sug na 'n sieklike verbruikersmentaliteit, waar mense gewerf word om verbruikers van die gemeente se produkte of religieuse programme te wees, voed nie.

- Dit moenie die fenomeen van 'circulation of the saints' of 'church shopping' (McManus 2001:29-30; Olivier 2005:134) versterk en bevorder nie. Lidmate van gemeentes en kerke loop dikwels oor na ander kerke omdat dit lekkerder is daar. Die groei wat dan in dié kerke plaasvind, kan nie gereken word as legitieme groei nie.
- Ware groei sal wees waar ongelowiges (heidene) tot geloof kom en by die plaaslike gemeente inskakel óf waar kerklos- en vervreemde lidmate opgespoor en weer geaktiveer word om aktief in die gemeente te wees. Dreyer (1998:310) meen dat 'n groter missionêre bewussyn nie primêr gaan om lidmaatgetalle te verhoog nie, maar omdat dit wesenlik deel is van ons lewe voor God.

- 'n Missionale bewussyn by elke lidmaat vereis 'n wesenlike besef van sendeling-wees en gestuurdheid in hierdie wêreld. 'The church doesn't exist to satisfy the consumer demands of believers; the church exists to equip and mobilize men and women for God's mission in the world' (McLaren 2001:157).

\section{Werkswyses van die missionale gemeente}

Die kerk het, teologies-gesproke, geen ander identiteit as 'n missionale identiteit nie. Die kerk is missionaal in wese, of anders is dit nie kerk nie. Gemeentebou dra 'n basiese besorgdheid en passie daarin om gemeentes te help om hierdie missionale identiteit te verstaan en te herontdek (Nel 2002:54-55). Marais en Kok (2005) se gedagtegang sluit hierby aan as hulle sê:

Missionale kerk-wees beteken dat gemeentes 'n meer kritiese ingesteldheid jeens hul omringende konteks ontwikkel, om sodoende as alternatiewe gemeenskap 'n uiters noodsaaklik profetiese roeping daarbinne te beoefen.

(Marais \& Kok 2005:174)

\section{'n Getuigende gemeente}

Die gemeente is die draer en beskermer van die waarheid (1 Tim 3:15). Dit spreek vanself dat die gemeente 'n belangrike fokuspunt as getuigende gemeenskap is. Dit geld die erediens, asook die prediking wat in die gemeente moet tuiskom. Cilliers (2002:146) is ook van mening dat lidmate wat in die kerkbanke sit, as gawe van God gesien sal word, eerder as godsdienstige kliënte wie se belange so goed as moontlik hanteer moet word. Dit beteken dat lidmate elke Sondag as gawes in die erediens byeenkom om versterk en toegerus te word vir hulle 'gestuurde-gawe-wees' in hulle lewenswêreld, buite die mure van die kerkgebou. Missionale prediking wil mense uitnooi om deel te word van God se voortgaande missie in die wêreld (De Bruin 2006).

Alle Christene word geroep om te getuig (vgl. Bosch 1991:137; Van der Spuy 2004:107; Keifert 2006:131-137). Hancke (2005:23) voer aan dat 'n sinergie tussen die persoonlike getuienislewering van lidmate en die korporatiewe impak van die gemeente bestaan. 'It is therefore imperative that the impact of the local Church will not be accelerated without concentrating on the personal witness of believers' (Hancke 2005:23). Daar kan geen korporatiewe getuienis wees sonder persoonlike getuienisse nie. Getuienislewering volgens Hancke (2005:135) is doelbewus (intentional): 'More emphasis should probably be placed on intentional witness than on conscious witness'. Die rede daarvoor is dat iemand bewus mag wees van die impak van 'n goeie lewe, hoewel dit nog 
nie bewustelike getuienis is nie:

Although it is not everything, evangelism still forms the heart of mission. This also applies to witness - if there is no intention to witness, then there is no witness.

(Hancke 2005:135)

Saam met die intensionele, word 'n geloofwaardige lewenswyse veronderstel. Getuie-wees gaan oor optrede, woorde, aksies en teenwoordigheid: 'And when witnessing by proclamation, these words should be accredited by a congruent life-style' (Hancke 2005:139-140; vgl. Bosch 1991:137; Getz 2003:155-162).

Die kwessie van missionale eredienste en die persoonlike getuienis van lidmate het nie deel van die empiriese toetsing ten opsigte van missionale resultate uitgemaak nie. Empiriese toetsing in hierdie velde sou meebring dat elke gemeente verslag moes gee van missionale eredienste en ook van lidmate se getuienislewering in die gemeenskap. Dit verg ' $n$ onafhanklike studie in elkeen van hierdie twee terreine.

\section{Sending}

Guder (2000:20) sluit hoofsaaklik by Barth se siening van sending as missio Dei aan. In kort, kom dit daarop neer dat die Vader, Seun en Heilige Gees die kerk die wêreld instuur. Sending is nie primêr 'n aktiwiteit van die kerk nie, maar 'n eienskap van God. God is 'n missionêre God. Sending word daarom gesien as 'n beweging van God na die wêreld en die kerk as 'n instrument vir daardie sending. Die kerk is daar omdat daar sending is en nie andersom nie. Guder (2000:22) noem dat sending as vakgebied die die basis ontwikkel het waaruit missiologie ontwikkel het in 'n groot dissipline, terwyl dit effektief met ander teologiese areas geïntegreer is.

Brueggemann (2006:103) trek die lyn van die Ou Testament na die Nuwe Testament deur tot na die vroeë kerk om vandag se betekenis van sending te verreken. Sending gaan nie vir hom oor die heengaan na ander plekke met die veronderstelling dat sekere gebiede 'reeds oorwin' is, terwyl ander gebiede nog 'ingeneem' moet word, só asof die basis by die huis 'beveilig' is nie:

Rather, the sending means to be dispatched as alternative in every place where anti-creation powers rule ... it is to be understood as alternative community in the midst of concentional communities.

(Brueggemann 2006:103)

Daarteenoor meen Hancke (2006:34-35; kyk ook Bosch 1979:248) dat dit beter is om sending te beskryf as die kerk se oorsteek van grense, maar dan wel in die vorm van 'n dienskneg.

Sending in die plaaslike gemeente: ' $n$ Mens is terdeë onder die indruk dat daar wegbeweeg word van tradisionele terminologie soos sending en evangelisasie en dat 'nuwe missionale taal' hierdie terminologie wil oorbrug en selfs verberg. Tog is daar die vraag of nuwe taalgebruik en terminologie nuwe stimulus en missionale ywer gaan bewerkstellig. Nuwe taalgebruik en terminologie mag 'n nuwe bewussyn help vestig en (hopelik) selfs 'n brandende passie, maar daar is tog grense wat ons met die beste taalgebruik nie kan misken nie. Hierdie grense is gegewe en is beslis bedoel om oorgesteek te word, maar die prominensie van die grense moet verreken word en die oorsteek daarvan verg 'n eiesoortige beplanning en strategie.

Die term 'sending' het myns insiens steeds gebruikswaarde, veral in die Suid-Afrikaanse konteks. Waar sending tradisioneel gesien is as die oorsteek van grense, verkieslik geografiese grense na ander lande, is dit by ons tans heel anders. In Suid-Afrika het ons die situasie waar die uithoeke van die wêreld, die Samaria's en die Judea's na Jerusalem toe stroom. Volgens 'n opname van United Assocation of South Africa (UASA) in 2006 word bereken dat Suid-Afrika die tuiste van tot soveel as 10 miljoen (20\% van die bevolking) onwettige immigrante is. 'n Ganse sendingveld is besig om oor ons grense te stroom en om hulle regoor die land te vestig. Dit is duidelik dat die regering nie by magte is om hierdie golf van onwettige immigrante te stuit nie en dat hulle verblyf hier permanent gaan wees (Die Hervormer 2007:2). Daar is bykans nie 'n gemeenskap in Suid-Afrika wat nie tans met vreemdelinge, veral uit ander Afrikalande gekonfronteer word nie. Dit is daarom dat die volgende definisie by uitstek geskik is om die 'nuwe sendingveld' in ons midde te bereik. Sending is die doelbewuste oorsteek van geografiese, sosiale, politieke, etniese, kulturele, godsdienstige en ideologiese grense deur die kerk om die evangelie met woord en daad aan die nie-kerk te verkondig. Die grense kan die straat, die woongebied, die kleur-, etniese-, kulturele- of watter grense ook al wees wat jou van die nie-kerk skei.

Neem byvoorbeeld 'n Nigeriese gesin wat 'n plakkershuis opslaan in 'n nuwe informele nedersetting teenaan die tradisionele Swart woongebied. Grenslyne is onmiddellik 'n gegewe en verskil figuurlik-gesproke in dikte tussen byvoorbeeld mense in die informele nedersetting, die Swart woongebied en dié in die tradisionele Wit dorp. Mense in die gevestigde Swart woongebied mag die bure uit die nedersettings as indringers beskou, wat hulle van potensiële werkgeleenthede kom beroof, terwyl inwoners in die tradisionele Wit dorpsgebied (waarin heel party Swart mense deesdae woon) hulle as ongenooid kan beskou en die groeiende plakkerskamp met argwaan bejeën. Dan is grenslyne soos taal, kultuur, godsdiens en ideologie nog nie eens in ag geneem nie.

Dan het daar ook gebeure plaasgevind wat, talle onwettige immigrante, soos die denkbeeldige Nigeriese gesin, tot in hulle wese geruk het. Die land het gedurende Mei/ Junie 2008 onder 'n vlaag vreemdeling-aanvalle gesteier en duisende paniekbevange immigrante het inderhaas die land uitgevlug, terwyl talle steeds in vrees en bewing 'n onwelkome tuiste hier probeer vind. Dit moet tot beskaming van die kerk in Suid-Afrika gesê word dat ons nie by magte was om vreemdelingehaat te kon omkeer en positief in die evangelisasie van duisende wat die grense na die RSA oorgesteek het, te kon kanaliseer nie. Die kerk (lees 75\% van Suid-Afrikaners, volgens nuutste sensus) het skamelik gefaal 
toe 'n sendingveld van miljoene Afrikane geografiese, sosiale, politieke, etniese, kulturele, godsdienstige en ideologiese grense na ons oorgesteek het. Daar is tans na afloop van die Fifa 2010 wêreldbeker opnuut sporadiese voorvalle van vreemdeling-aanvalle wat opnuut vrese laat ontstaan dat 'n volskaalse etniese suiwering mag plaasvind.

Miskien moet daar in die Suid-Afrikaanse konteks gepleit word vir begrip dat daar figuurlik-gesproke, harder en sagter grenslyne is. Soliede, dik lyne of dun en selfs stippellyne; alles grenslyne wat die kerk na die nie-kerk moet oorsteek. Vir die soliede, dik lyne is die term sending steeds 'n doeltreffende voertuig en vir die dun en gestippelde lyn bied die term evangelisasie steeds genoegsame drakrag. Evangelisasie sou dan geld vir diegene in die gemeenskap wat in terme van taal en kultuur (om maar enkele voorbeelde te noem) meer toeganklik is. Natuurlik kom die begrippe steeds tuis onder die sambreelterm 'missionaal' of die apostolaat van die kerk, soos Van der Merwe (Die Hervormer 2009:1) voor pleit, hoewel, die begrippe sending en evangelisasie myns insiens nie só uitgedien is as wat algemeen aanvaar word nie. Die oproep behoort te wees dat 'n groter missionale bewussyn as gevolg van 'n sendingveld wat na ons toe gekom het, sal posvat. Die grootste, soliede dik grenslyn wat stellig oorbrug moet word, is dié van vooroordeel, en 'n houding van 'hullehoort-nie-hier-nie'.

Met Hancke (2006:120-122; vgl. Die Hervormer 2009:1) se vermaning in gedagte, dat daar gewaak moet word teen die persepsie dat sending slegs een van die aksies in die gemeente is, kan daar tog gevra word na spesifieke aksies wat die gemeente loods of by betrokke is, welwetende dat die gemeente haar missionale karakter sal bly ontwikkel ten einde meer en meer ' $n$ gestuurdheid te openbaar. Die volgende het as vrae gedien by die empiriese toetsing:

- Is u gemeente by die opleiding van sendelinge betrokke?

- Verleen u gemeente finansiële steun vir sending in die algemeen?

- Doen $\mathrm{u}$ toegespitste voorbidding vir sending of sendelinge?

- Is $\mathrm{u}$ gemeente betrokke by die lewensonderhoud van sendelinge?

- Is $\mathrm{u}$ gemeente betrokke by korttermyn-sendinguitreike en wat is die frekwensie daarvan?

- Is daar lidmate wat die afgelope 5 jaar as gevolg van $\mathrm{u}$ gemeente se sendingaksie by $\mathrm{u}$ belydenis van geloof afgelê het?

Bevinding ten opsigte van sendingwerk in deelnemende gemeentes: Daar was volgens die statistiese toetse nie betekenisvolle verskille tussen die twee groepe gemeentes nie, hoewel die vergelykende tabelle tog tendense tussen die twee groepe gemeentes aandui. Dit blyk wel dat gemeentebougemeentes groter fisiese aktiwiteit in terme van opleiding van sendelinge, uitreike, buitelandse bestemmings, asook die heraktivering van lidmaatskap en die aflegging van geloofsbelydenis getoon het. Wat statiese aktiwiteite betref, het die nie-gemeentebougemeentes beter vertoon, soos byvoorbeeld finansiële bydraes en voorbidding vir sendelinge. By die heraktivering van lidmaatskap blyk dit dat die gemeentebougemeentes by die mediaan met 3 punte beter gevaar het en by die belydenisaflegging was die gemeentebougemeentes 1 punt beter daaraan toe.

'n Totaal van 57.5\% gemeentebougemeentes het aan korttermyn sendinguitreike deelgeneem, teenoor $54.1 \%$ van die nie-gemeentebougemeentes. Gemeentebou-gemeentes het by meer buitelandse bestemmings aangedoen as die niegemeentebougemeentes. Botswana, gevolg deur Mosambiek blyk die gewildste bestemmings te wees, waarskynlik omdat daar meer onbereikte gemeenskappe in baie ongerepte dele van hierdie lande is. Dit kan ook wees dat hierdie bestemmings 'n groter komponent van avontuur inhou en ook na 'n meer tradisionele manier van sendingdoen vra. Van die ander buitelandse bestemmings wat opgeval het was Soedan, Turkye, Jemen, Aalst in België, Guatemala en Indië.

Dit was bemoedigend om te sien dat daar gemeentes is wat binnelandse bestemmings aangedui het, terwyl daar ook plaaslik gefokus is, veral noudat 'n groeiende sendingveld uit eie oorweging oor ons landsgrense stroom en hulle in ons midde kom tuismaak.

\section{Evangelisasie}

Volgens Heitink (2007:190) is die term evangelisasie 'een prikkelend woord ... dat oude papieren heeft, daarna in het verdomhoekje belandde, maar in onze tijd op een open levensbeschoulijke markt een herkansing verdient'. Een van die redes dat die term evangelisasie in die 'verdomhoekje' beland het, is die opdringerige benadering wat in die verlede in die proses van 'Zieltjes winnen' gevolg is waar bekeringsywer (dwang) meestal die doel verbygeskiet het (Heitink 2007:192).

Die hele saak van evangelisasie vra na die regte balans. Dit behoort nie net ' $n$ losstaande program te wees wat êrens aan die gemeentebediening gehaak word nie, maar moet eerder spruit uit 'n deurleefde missionale bewoëndheid:

Mission is not something the Church does, a part of its total program. No, the Church's essence is missional, for the calling and sending action of God, forms its identity. Mission is founded on the mission of God in the world, rather than the Church's effort to extend itself.

(Guder 1998:81)

McLaren (2001) deel hierdie mening as hy sê:

Our mission is comprehensive - so that every Christian, 'clergy' and 'lay', is equally sent - to a classroom, a factory, an office building, a highway, a jungle, whatever - to be an agent of Christ, an agent of the kingdom.

(McLaren 2001:156)

Evangelisasie het die bedoeling om mense buite die gemeente in die voorregte van die evangelie te laat deel. Dit gaan hier nie net oor woorde van genade en waarheid nie, maar ook oor dade van barmhartigheid en geregtigheid (Heitink 2007:194; vgl. Dulles 2002:211-212). Barret (1987:77) wys daarop dat daar in Engels meer as 300 verskillende definisies van die konsep 'evangeliseer' (evangelise) is: '... using vastly 
different terminology and employing over 700 different terms or synonyms or near-synonyms of part-synonyms'. Evangelisasie kan volgens Bosch (1991) opgesom word as:

Daardie dimensie en aktiwiteit van die kerk se sending wat deur woord en daad en in die lig van spesifieke omstandighede en in ' $n$ bepaalde konteks aan elke persoon en gemeenskap, oral 'n geldige geleentheid tot ' $n$ radikale heroriëntasie bied en sluit aspekte in soos bevryding van slawerny aan die wêreld en sy magte; om Jesus Christus aan te gryp as Redder en Heer; en 'n lewende lidmaat van sy gemeente te word; betrokke te raak in sy diens van rekonsiliasie, vrede, geregtigheid op aarde en om toegewy te wees aan God se doel om alles onder die heerskappy van Christus te stel.

(Bosch 1991:420)

Die volgende vrae oor evangelisasie is aan die respondente gestel:

- Het u gemeente die afgelope vyf jaar een van die volgende evangelisasiekursusse aangebied naamlik Evangelism Explosion (EE3), Getroue Getuie kursus, Alpha kursus? Geleentheid is ook gegee om ander kursusse te vermeld.

- Hoeveel lidmate het die bepaalde kursus die afgelope 5 jaar bygewoon?

- Doen u gemeente evangelisasiegerigte sensus?

- By hoeveel geïdentifiseerdes is daar evangelisasie gedoen?

- Hoeveel lidmate was as gevolg van evangelisasiewerk deur middel van belydenisaflegging en heraktivering van lidmaatskap ingeskakel?

Bevinding ten opsigte van evangelisasie in deelnemende gemeentes: Die Getroue Getuie-kursus (40\%) word meer as die EE3-kursus (30\%) deur gemeentebougemeentes aangebied. Die rede is waarskynlik geleë in Malan Nel se opleiding van Getroue Getuie-aanbieders, wat meerendeels uit die gemeentebougemeentes kom. Statistiese toetsing dui aan dat betekenisvol meer gemeentebougemeentes die Getroue Getuie-kursus aanbied as die nie-gemeentebougemeentes. Die EE3-kursus is deur 25.9\% van die respondente gebruik, terwyl 28.4\% die Getroue Getuie-kursus gebruik het. Dit blyk dat die Getroue Getuie-kursus in die 17 jaar van sy bestaan in Suid-Afrika aansienlik veld gewen het teenoor die EE3kursus wat reeds vir ongeveer 27 jaar in die land aangebied word. Die Alpha-kursus het nie prominente status onder die respondente geniet nie.

Die respondente het ' $n$ aantal interessante 'ander kursusse' aangedui, waarmee hulle lidmate vir evangelisasiewerk toerus. Die syfers in hakies dui die aantal gemeentes aan wat die bepaalde kursus aangebied het:

- vennootskap van gestuurde gemeentes

- Bybel in ons lewe-kursus (3)

- eie kursusse (3)

- Moslem-uitreik-kursus

- spesifieke seltoerusting vir bereiking van buitekerklikes

- CEF (Child Evangelism Fellowship)

- Kinder + jeug EE3

- 30- KD

- See you at the party

- Book of hope: skoleprojek

- Petra-woordlose boek vir die getraumatiseerde kind
- Just walk across the room (3)

- Kingfisher

- die wese van dissipelskap (2)

- How to become a contagious Christian van Bill Hybels (2)

- 12 sleutels tot geestelike groei

- GETP (Gemeentelike Evangelisasie Toerustingsprogram).

Dit blyk dat 28 gemeentebougemeentes 'n gemiddeld van 36 lidmate vir evangelisasiewerk met die EE3- en Getroue Getuiekursusse toegerus het, terwyl 11 nie-gemeentebougemeentes 'n gemiddeld van 30 lidmate met dieselfde kursusse toegerus het. Daar het ook 'n groter gemiddelde getal lidmate by die nie-gemeentebougemeentes, die Getroue Getuie-kursus bygewoon as die getal by die gemeentebougemeentes. Wanneer EE3 en Getroue Getuies saam bereken word is die gemeentebougemeentes se gemiddeld hoër, soos blyk uit die vorige punt. By die ander kursusse (22\% van respondente) wat aangebied is, blyk dit dat nie-gemeentebougemeentes geneig is om meer met sulke kursusse te eksperimenteer, terwyl 'n saak uitgemaak kan word dat gemeentebougemeentes eerder by die konvensionele kursusse (EE3 en Getroue Getuies) wat hulle oor tyd heen bewys het bly.

Daar is ' $n$ geringe meerderheid gemeentebougemeentes (4\%) wat evangelisasiegerigte sensus doen. Die respondente by die gemeentebou-gemeentes het by byna die helfte (mediane 30 vs. 18) meer geïdentifiseerdes evangelisasiewerk gedoen as die nie-gemeentebou-gemeentes, hoewel die statistiese toetse dit in terme van die groter geheel nie as statisties-betekenisvol aandui nie. Wat die heraktivering van lidmaatskap danksy evangelisasiewerk betref, blyk dit dat die gemeentebougemeentes betekenisvol beter gedoen het, soos bevestig deur die statistiese toetse. Wat belydenisaflegging betref, het die gemeentebougemeentes 'n hoër gemiddeld as die niegemeentebougemeentes.

Wat evangelisasie in geheel betref, is daar 'n duidelik waarneembare tendens in die guns van gemeentebougemeentes. Dit word afgelei uit die geheelbeeld van gemiddeldes en mediane, asook statistiese toetse wat aangedui het dat gemeentebougemeentes in twee fasette betekenisvol beter gedoen het.

\section{Kleingroepe in die missionale gemeente}

Kleingroepe is volgens Arnold (1992:9) 'an intentional gathering of three to twelve people who commit themselves to work together to become better disciples of Jesus Christ'. Die drie sleutelterme hier is 'commitment', 'working together' en 'discipleship'. Olivier (2005:224) noem dat 'n kleingroep 'n doelbewuste byeenbringing van drie tot twaalf indiwidue behels, wat op ' $n$ gereelde basis byeenkom met die doel om mekaar effektief toe te rus en te bemagtig tot groei in Christusgelykvormigheid. Die voordele van 'n kleingroepbediening in die gemeente is welbekend, soos koinonia wat bewerkstellig word byvoorbeeld (Arnold 1992:42; Van der Spuy 2004:145-150; Olivier 2005:255); aanbidding en lofprysing (Van der Spuy 1998:32); Woordstudie (Van der Spuy 1998:33, 2004:145-146); dienswerk (vgl. Nel 1994:92; Van der Spuy 2004:155-165); onderlinge dissipline (Nel 
1994:94) en leierskapsontwikkeling (Olivier 2005:245) om maar enkeles te noem. Daarmee saam die belangrike aspek van 'n missionale gerigtheid. Getuienislewering behoort deel te wees van die kleingroep se missionale bewussyn. Nuwe lede moet gedurig by die groep gevoeg word. George (1992:100,128; Olivier 2005:246; vgl. Hancke 2006:182) stel 'n ideaal van twee persone elke jaar. Om die lede aan hierdie visie te herinner, stel hy voor dat daar 'n 'oop stoel' by elke geleentheid moet wees, sodat daar gebid en gewerk kan word om daardie stoel gevul te kry.

Volgens Myers (2003:18), behoort net ongeveer 30\% van 'n gemeente se lidmate aan kleingroepe. Dit is dwingend noodsaaklik dat hierdie 30\% lidmate wat weekliks vergader, opgelei word om hulle groep 'n misssionale kleingroep te maak. Die missionale waarde van 'n kleingroepbediening lê daarin dat nog-nie-gelowiges dalk makliker by 'n kleingroep as by ' $n$ erediens sal kom inloer. Die blote aanwesigheid van kleingroepe in 'n gemeente kan ' $n$ aanduiding van ' $n$ missionale gerigtheid wees, veral as die 'oopstoel-gedagte' gedurig bevorder en uitgevoer word. Deelnemende gemeentes is aan die hand van die volgende vrae getoets:

- Die hoeveelheid kleingroepe in die gemeente?

- Word die kleingroepe aangemoedig om nuwe mense te nooi?

- Hoeveel kleingroepe reik uit na die gemeenskap?

- Aantal lidmate deur middel van kleingroepbedieining toegevoeg?

Bevinding ten opsigte van kleingroepbediening en missionale sukses: Die hele saak van kleingroepe het goed posgevat onder gemeentes in die algemeen. Dit blyk dat gemeentes uit die gemeentebougroep meer kleingroepe gevestig het. Dit lyk ook of beide groepe in die algemeen erns maak met die 'oopstoel' gedagte en wel nie-gelowige en kerkvervreemde mense na hulle byeenkomste toe uitnooi. Daar was ook meer kleingroepe van die gemeentebougemeentes in die gemeenskap betrokke en hulle kon ook daarin slaag om meer nie-gelowiges en kerkvervreemdes by die gemeente in te skakel.

Kleingroepe toon tog, wat die missionale betref, 'n effens beter suksessyfer as die normale evangelisasiewerk in 'n gemeente, hoewel die statistiese toetse nie definitiewe afleidings regverdig nie. By nie-gemeentebougemeentes wil dit lyk of die tradisionele manier van evangelisasiewerk, eerder as kleingroepbediening vir hulle ietwat meer vrugte afwerp. Tog blyk dit dat kleingroepe oor die algemeen nie genoegsaam daarin slaag om nie-gelowiges en kerkvervreemdes by die gemeente in te skakel nie. Daar is waarskynlik steeds te veel van 'n na-binne-gerigtheid by kleingroepe. In die algemeen beskou, dui die syfers ten opsigte van kleingroepe se missionale werking 'n meer gunstige tendens by die gemeentebougemeentes aan as wat die geval by die nie-gemeentebougemeentes is.

\section{'n Gemeente wat bestaan om ander te dien}

Armstrong (1979:60) meen dat die Christelike geloof oor persoonlike interaksie gaan wat sentreer in 'n verhouding met
Jesus Christus, maar ook omdat dit deur persone oorgedra word: 'Christianity is a person-to-person religion'. Alles wat ons van Christus hoor, weet of lees, is die resultaat van mense wat onder leiding van die Heilige Gees geskryf het wat hulle geskryf het: 'Christianity is a religion about a person, from persons ... but it is more. It is for persons' (Armstrong 1979:60). In sy studie oor die werk van Newbigin, formuleer Hunsberger (1998) Newbigin se siening is soos volg:

... the best way to meet society in terms of the gospel - and avoid the possiblity of compromise - is for Christians [to] be the hermeneutic of the gospel - the interpretive lens through which people will see and read what the gospel has to do with them and the world in which they live.

(Hunsberger 1998:279)

DeClaissé-Walford (2008:6) ondersteun die gedagte en noem dat die Christendom fundamenteel oor gemeenskapsbetrokkenheid gaan. Hy gebruik die Bybelse beelde van sout en lig (Matt 5:13-16) en stel dit soos volg: '... and I take this to mean that the church are less about numbers and more about effect'.

Die werk van Moffitt (2006) werp goeie lig op die hele saak van diensevangelisasie en fisiese, sosiale bediening. Hy identifiseer ses redes waarom die plaaslike gemeente die gemeenskap kan beïnvloed (Moffitt 2006:179-181):

- Die plaaslike gemeente het ' $n$ holistiese mandaat. Dit sluit alle aspekte van die indiwidu en gemeenskap se lewe, naamlik hul fisiese, spirituele, sosiale en intellektuele behoeftes in. God se breëre agenda maak dat die gemeente bedieninge in al die areas van mense se lewens bewerkstelllig.

- Die plaaslike gemeente bied voortdurende toerusting vir sy mense. Toerusting geskied deur middel van eredienste, Bybelstudiegroepe, kategese, kleingroepe ensovoorts: 'Equiping is far more than knowledge. It provides preparation and experience. It developes people's skills, attitudes, understanding, abilities, spiritual gifts, faith and faithfulness' (Moffit 2006:180).

- Die plaaslike gemeente verteenwoordig 'n breë spektrum van die gemeenskap. As gemeenskap van gelowiges verteenwoordig die plaaslike gemeente alle sosioekonomiese klasse, etniese groepe, opvoedkundige vlakke en beroepe. Hierdie mense kan weer oral in hulle onderskeie leefwêrelde 'n verskil maak.

- Die plaaslike gemeente is inheems. Die lidmate en leiers kom uit die gemeenskap wat die plaaslike gemeente bearbei.

- Die plaaslike gemeente se bediening is volhoubaar. Die plaaslike gemeente onderhou haarself uit eie bronne en die uitreike is uit eie middele. Baie organisasies kom van buite af en moet gedurig geld en middele van buite genereer wat, sonder die volgehoue ondersteuning van buitepersoneel en hulpbronne, moeilik is om vol te hou.

- Die plaaslike gemeente is ontwerp vir lewenslange betrokkenheid met haar lidmate: 'There are few other institutions where people come voluntarily, regularly, throughout their lives, to receive instruction about how to live' (Moffit 2006:181). 
Nel (1994:232) stel dit duidelik as hy sê dat die gemeente die barmhartigste organisme op aarde behoort te wees. Daarby kan dit sterk gestel word dat die diakonaat nie ter wille van die bekering van mense gedoen word nie. Die werk van barmhartigheid word gedoen deur die kerk uit dankbaarheid vir eie verlossing en al die goeie gawes wat ontvang word, omdat God sy son laat skyn oor goeies en slegtes. Tog lewer die diakonaat sy groeivrug wanneer mense tot geloof kom (Nel 1994:232); die eer en die dank kom altyd die Vader toe. By die empiriese toetsing is twaalf voorbeelde van missionale uitreike in die gemeenskap gestel waar gemeentes hulle betrokkenheid kon aandui, naamlik:

- sopkombuise

- verskaffing van niebederfbare voedsel

- verskaffing van klere en komberse

- voorsiening van deurgangbehuising

- versorging van straatkinders

- voorsiening van behuising aan behoeftiges

- betrokkenheid by terminale sorg

- betrokkenheid by ouetehuise

- betrokkenheid by kinderhuise

- verskaffing (gratis) van gemeentefasiliteite aan instansies wat gemeenskapswerk doen

- verskaffing (gratis) van gemeentefasiliteite vir opvoedkundige doeleindes en betrokkenheid by plakkerskampe.

Respondente kon ook ander punte van betrokkenheid aandui waarby die gemeente betrokke is.

Bevinding ten opsigte van diens aan die gemeenskap: Daar was 'n baie goeie antwoordsyfer ten opsigte van die 12 projekte wat as voorbeelde voorgehou is, naamlik tussen $87.7 \%$ en $96.3 \%$, wat op 'n gesonde besef van gemeentes se verpligting teenoor die gemeenskap ten opsigte van barmhartigheidsdiens dui. Wat betrokkenheid by vigs- en ander terminale pasiënte betref, is die betrokkenheid van die gemeentebougemeentes meer betekenisvol as dié van die nie-gemeentebougemeentes. Die gemeentebougemeentes was, oor die algemeen beskou, heelwat meer by die twaalf soorte projekte betrokke (61\%), vergeleke by die 39\% van die nie-gemeentebougemeentes, hoewel daar nie statistiesbetekenisvolle verskille uitgewys kan word nie.

By die aflegging van geloofsbelydenis het die niegemeentebougemeentes aansienlik beter gevaar as die gemeentebougemeentes, terwyl die rolle by heraktivering van lidmaatskap net so omgeruil is. Die klein getal gemeentes by beide groepe wat hier waardes aangedui het regverdig nie enige betekenisvolle afleidings nie, soos wat die toetse dan ook uitwys.

Die respondente is ook gevra na hulle mening oor hulle rol in die gemeenskap en die gemeenskap se siening van die gemeente. Wat hulle impak op die plaaslike gemeenskap betref, het beide groepe 'n positiewe selfbeeld openbaar, met gemeentebougemeentes wat ietwat meer optimisme openbaar het. Beide groepe het aangedui dat die gemeenskap oorwegend 'n gunstige siening ten opsigte van hulle gemeentes het.
In die geheel gesien, het die gemeentebougemeentes beter as die nie-gemeentebougemeentes vertoon.

\section{Samevatting}

In die lig van alles wat tot dusver gesê is, word bevind dat die hipotesestelling geverifieer kan word. Gemeentes wat besig is met ' $n$ gestruktureerde gemeentebouproses is missionaal meer suksesvol as gemeentes wat geen gestruktureerde gemeentebouproses deurloop nie. Die gemeentebougemeentes het in die algemeen en deurlopend beter gereageer as respondente, die statistiese gegewens was oor die algemeen meer in die guns van die gemeentebougemeentes, met enkele statistiese toetse wat ook betekenisvol ten gunste van die gemeentebougemeentes beslis het.

Ten spyte van die bevinding in die guns van die gemeentebougemeentes, is daar rede tot kommer. Die geheelbeeld wek die indruk dat gemeentes in die algemeen gebrek ly aan 'n grondige missionale identiteit en die behoorlike uitlewing daarvan. Die vermoede bestaan dat daar nog te veel op instandhouding gefokus word in die gemeente en dat 'n oorwig lidmate in gemeentes steeds weinig verstaan van wat die beteken om gestuurdes in hulle wêreld te wees. In die toekoms sal die missionale beginsels wat reeds in gemeentebouliteratuur vervat is, meer ontgin en doelgerig toegepas moet word.

\section{Literatuurverwysings}

Almanak \& Bybelse Dagboek, 2009, Nederduitsch Hervormde Kerk van Afrika Jaargang 100, Sentik, Pretoria.

Armstrong, R.S., 1997, Service Evangelism, Westminster Press, Philadelphia, PA.

Arnold, J., 1992, The Big Book on Small Groups, Intervarsity Press, Downers Grove, IL.

Barna, G., 2005, Revolution: Worn out on church? Finding vibrant faith beyond the walls of the sanctuary, Christian Art Publishers, Vereeniging.

Barret, D.B., 1987, Evangelize: A Historical Survey of the Concept, New Hope, Birmingham.

Beukes, M.J. du P., 1995, 'Evaluering van verskillende gemeenteboumodelle met die oog op die daarstelling van ' $n$ eie model vir die Nederduitsch Hervormde Kerk van Afrika', HTS Teologiese Studies/ Theological Studies 51, 806-824.

Bisschoff, J.H., 1991, 'Gemeentebou: 'n Prakties-Teologiese basisteorie', DD-proefskrif, Department Praktiese Teologie, Universiteit van Pretoria.

Bisschoff, J.H., 1998, Kleingroepbediening, ongepubliseerde lesing oor kleingroepe, Aangebied by die NG gemeente Skuilkrans, Pretoria.

Black, J.S. \& Gregersen, H.B., 2008, It starts with One: Changing Individuals Changes Organizations, Pearson Education, Inc., Upper Saddle River, New Jersey, NJ.

Bosch, D.J., 1979, Heil vir die wêreld, N.G. Kerkboekhandel Transvaal, Pretoria.

Bosch, D.J., 1991, Transforming Mission: Paradigm Shifts in Theology of Mission, Orbis Books, New York, NY.

Brueggemann, W., 2006, The Word that redescribes the World: The Bible and Discipleship, Augsburg Fortress Press, Minneapolis, MN.

Callahan, K.L., 1990, Effective Church Leadership: Building on the twelve Keys, HarperCollinsPublishers, San Francisco, CA.

Callahan, K.L., 2000, Small, Strong Congregations, Jossey Bass, San Francisco, CA.

Cilliers, J., 2002, 'Die geheim van prediking: In-stemming met die gemeente', HTS Teologiese Studies/Thelogical Studies 58(1),143-156.

De Bruin, D., 2006, 'Missionêre eredienste', besigtig 17 Junie 2008, by http://www. ngkerk.org.za/artikel.asp id $=85 \&$ katid $=27 \&$ posisie $=1 \&$ status $=b \&$ sinid $=22$

DeClaissé-Walford, S., 2008, Mission as Holistic Ministry: Developing a Congregationa Ethos of Community Engagement, Smyth \& Helwys Publishing, Inc., Macon, GA.

Dreyer, T.F.J., 1998, 'Spiritualiteit, identiteit en die etos van die Nederduitsch Hervormde Kerk', HTS Toelogiese Studies/Theological Studies 54(1\&2), 289-314.

Dreyer, T.F.J., 2003, 'Statistieke vertel 'n storie: 'n Visie vir die Hervormde Kerk op pad na 2010', HTS Teologiese Studies/Theological Studies 59, 1045-1062.

Dreyer, W.A., 2009, Missionale bediening, ongepubliseerde korrespondensie aan die Raad vir Apostolaat, Nederduitsch Hervormde Kerk van Afrika, 05 Februarie 2009. 
Driscoll, M., 2006, Confessions of a Reformission Rev: Hard lessons from an emerging missional church, Zondervan, Grand Rapids, MI.

Dulles, A., 2002 [1974], Models of the Church, expanded edn., Doubleday, New York, NY.

Du Plessis, I.J., 1962, Christus as hoof van kerk en kosmos: 'n Eksegetiese-teologiese studie van Christus se hoofskap veral in Efesiërs en Kolossense, VRB Kleine der A 3-4, Groningen.

Getz, G.A., 1984, Sharpening the focus of the Church, Victor Books, Wheaton, IL.

Getz, G.A., 2003, Elders and Leaders: God's plan for leading the Church, Moody Publishers, Chicago, IL.

Gibbs, E., 1993, Winning Them Back: Tackling the Problem of Nominal Christianity, Monarch Publications, Tunbridge Wells.

Gibbs, E., 2000, ChurchNext: Quantum Changes in how we do Ministry, InterVarsity Press, Downers Grove, IL.

Guder, D.L., 1998, Missional Church - A vision for the sending of the Church in North America, Eerdmans Publishing Company, Grand Rapids, MI.

Guder, D.L., 2000, The Continuing Conversion of the Church, Eerdmans Publishing Company, Grand Rapids, MI.

Hancke, F.J., 2005, 'Factors influencing comprehensive personal witness and enlarging missional involvement in the local church', PhD thesis, Department of Missiology, University of the Free State.

Hancke, F.J., 2006, Ons is die plan: Die gemeente met 'n verskil maak ' $n$ verskil... Universiteit van Pretoria, Instituut vir Sendingwetenskaplike en Ekumeniese Navorsing (ISWEN), Pretoria.

Heitink, G., Van de Meent, J. \& Stoppels, S., 1998, Een gezamenlijke trektocht Meedenken met Jan Hendriks over gemeenteopbouw, Kok, Kampen.

Heitink, G., 2007, Een kerk met karakter: Tijd voor heroriëntasie, Kok, Kampen.

Hendriks, H.J., 1992, Strategiese beplanning in die gemeente, Hugenote, Wellington.

Hendriks, H.J., 2004, Studying Congregations in Africa, Lux Verbi.BM., Wellington.

Hendriks, J., 1990, Een vitale en aantrekkelijke gemeente: Model en methode van gemeenteopbouw, Kok, Kampen.

Hirsch, A., 2006, The Forgotten Ways: Reactivating the Missional Church, Brazos, Grand Rapids, MI.

Hoek, J., 1999, Gemeentezijn: Dat houdt wat in, Uitgeverij Boekencentrum, Zoetermeer.

Hunsberger, G.R., 1998, Bearing the witness of the Spirit: Lesslie Newbigin's Theology of Cultural Plurality, Eerdmans, Grand Rapids, MI.

Keifert, P.R., 2006, We are here now: A new missional era. A missional journey of spiritual discovery, Allelon Publishing, Eagle, ID.

Mann, A., 1999, Can our Church Live? Redeveloping Congregations in Decline, Alban Institute, Inc., Washington, DC.

Marais, J.F., \& Kok G., 2005, 'Missionêre Kerk, van sturend na gestuur. Vir kennisname en toeligting', Agenda: Sinode van Suid-Transvaal, 18-20 Oktober 2005, pp. $173-178$.

McLaren, B.D., 2001, A new kind of Christian: A tale of two friends on a Spiritual Journey, Jossey-Bass, San Francisco, CA.

McManus, E.P., 2001, An Unstoppable force: Daring to become the church God had in mind, Flagship Church Resources, Yates \& Yates, LLP, Literary Agents, Orange, CA.

Moffitt, B., 2006, If Jesus were Mayor: How your local church can transform your community, Monarch Books, Grand Rapids, MI.

Myers, J.R., 2003, Search to belong: Rethinking Intimacy. Community, and Small Groups, Zondervan, Grand Rapids, MI.
Nel, M., 1986, Teologiese Perspektiewe op Gemeentebou, N.G. Kerkboekhandel, Pretoria.

Nel, M., 1988, Fases in Gemeentebou, N.G. Kerkboekhandel, Pretoria.

Nel, M., 1994, Gemeentebou, Orion Uitgewers, Halfway House.

Nel, M., 1995, 'Gemeentebou: 'n Reformatoriese bediening', HTS Teologiese Studies/ Theolocial Studies 51(3), 858-864.

Nel, M., 2002, 'Missionêre koers van 58 gemeentes in Suid-Afrika. 'n Empiriese verslag', Praktiese Teologie in Suid-Afrika 17(1), 1010-8017.

Niemandt, N., 2007, Nuwe drome vir nuwe werklikhede: Geloofsgemeenskappe in pas met 'n postmoderne wêreld, Lux Verbi BM., Wellington.

'Nuwe koers vir apostolaat', Die Hervormer, Mei, 2009, p. 1.

Odendal, F.F. \& Gouws R.H., 2000, HAT: Verklarende Handwoordeboek van die Afrikaanse Taal, 4d uitg., 3de druk, Perskor Uitgewers, Midrand.

Oliver, E., 2006, 'Sunday School: Past and present', Studia Historiae Ecclesiasticae XXXII(1), 117-134.

Olivier, H.B., 2005, 'Die plaaslike missionêre gemeente in transformasie - met besondere verwysing na die kleingroep as voertuig vir die bevordering van koinonia', DD-proefskrif, Departement Praktiese Teologie, Universiteit van Pretoria.

'Redaksionele kommentaar', Die Hervormer, 15 Mei, 2007, p. 4.

Roberts, J.H., 1963, 'Die opbou van die kerk volgens die Efese-brief. Proefskrif ter vervulling van die graad Doctor in de Theologie te Kampen', V.R.B. - Kleine der A, Groningen.

Schwarz, C.A., 2005, Colour your world with Natural Church Development Experiencing all that God has designed you to be, NCD Australia.

Sider, R.J., Olson, P.N. \& Unruh, H.R., 2002, Churches that make a difference: Reaching your Community with Good News and Good Works, Baker Books, Grand Rapids, MI.

Stevens, P.R., \& Collins P., 1993, The Equiping Pastor: A systems approach to congregational leadership, Alban Institute, New York, NY.

Sweet, L.I., 1999, SoulTsunami: Sink or swim in new millennium culture, Zondervan, Grand Rapids, MI.

Te Velde, M., 1992, Gemeente Opbouw 1: Doelgericht en samenhangend werken in de christelijke gemeente, De Vuurbraak, Barneveld.

Van der Merwe, J.C., 1997, 'Die missionêre gerigtheid van die kerk', HTS Teolgiese Studies/Theological Studies 53(3), 705-721.

Van der Merwe, J.C., 2005, 'Hoop vir 2005', Die Hervormer, 01 Februarie, p. 5.

Van der Merwe, J.C., 2008, 'Skrywe aan die Kuratorium van die NHKA', 21 Julie 2008.

Van der Merwe, J.C., 2009, 'Nuwe koers vir apostolaat', Die Hervormer, Mei, p. 1.

Van der Merwe J.F. \& Vos C.J.A., 2002, “Die begrip "rentmeesterskap" in die gemeentebouproses', HTS Teologiese Studies/Theological Studies 58(1), 369-394.

Van der Spuy, D., 1998, Herlewing deur kleingroepe, Struik Christelike Boeke, Kaapstad.

Van der Spuy, D., 2004, Destined for Growth: Towards a deeper spiritual life, Struik Christian Books, Cape Town.

Van Staden, P., 2007, Kom ons praat oor die kerk ... Konteks, Jaargang 18 no 6. Junie 2007, p. 12-13.

Van Wyk, I.W.C., 2007, 'n Wêreldwye probleem, Konteks, Jaargang 18 no 6. Junie 2007 , p. $10-12$.

Warren, R., 1995, The Purpose Driven Church, Growth without compromising your message \& mission, Zondervan Publishing House, Grand Rapids, Ml.

Warren, R., 2002, Die Doelgerigte lewe, Jonathan Ball Uitgewers (Edms) Bpk met vergunning, Jeppestown. 